\title{
Acalypha indica Linn root extract improved hippocampal cell viability and increased Brain-derived Neurotrophic Factor (BDNF) in hypoxic condition
}

\author{
Nurhadi Ibrahim, ${ }^{1}$ Julia Rahadian, ${ }^{2}$ Dewi F. Suniarti ${ }^{3}$ \\ ${ }^{1}$ Department of Medical Physiology, Faculty of Medicine, Universitas Indonesia, Jakarta, Indonesia \\ ${ }^{2}$ Department of Physiology, Faculty of Medicine, Atma Jaya University, Jakarta, Indonesia \\ ${ }^{3}$ Department of Oral Biology, Faculty of Dentistry, Universitas Indonesia, Jakarta, Indonesia
}

\begin{abstract}
Abstrak
Latar belakang: Penelitian ini dilakukan untuk mengetahui pengaruh pemberian ekstrak akar Acalypha indica Linn (akar kucing) dalam memproteksi neuron kultur jaringan hipokampus tikus pada keadaan hipoksia.

Metode: Ini merupakan penelitian eksperimental in vitro pada kultur primer sel hipokampus tikus Sprague Dowley dewasa. Selain kelompok kontrol, sel dipajan ekstrak Acalypha indica Linn dosis $10 \mathrm{mg} / \mathrm{mL}, 15 \mathrm{mg} / \mathrm{mL}$, dan $20 \mathrm{mg} / \mathrm{mL}$ selama 72 jam. Kemudian seluruh kelompok sel diberi perlakuan hipoksia dengan gas-gas 5\% O2 5\% CO2 N2 balans selama 24 jam. Setelah itu viabilitas relatif sel diukur dengan 3-[4,5-dimethylthiazol-2-yl]-2,5-diphenyltetrazolium bromide (MTT), 5 -bromo2'-deoxy-uridine (BrdU) untuk proliferasi sel dan Brain-derived Neurotrophic Factor (BDNF) kit metode ELISA untuk kadar BDNF
\end{abstract}

Hasil: Viabilitas sel hipokampus yang terpapar ekstrak akar Acalypha indica Linn pada pemeriksaan MTT (C: 99,7\%, A indica L10: 326,3\%, A indica L 15: 411,7\%, A indica L 20: 445,9\%), BrdU absorbansi (C: 0,07, A indica L 10: 0,10, A indica L 15: 0,12, A indica L 20: 0,13), meningkat secara bermakna dibandingkan kontrol ( $\mathrm{p}<0,01)$ disertai peningkatan kadar BDNF (C: 11,3 pg/mL, A indica L 10: 12,5 pg/mL, A indica L 15:23,1 pg/mL, A indica L 20: $18,1 \mathrm{pg} / \mathrm{mL})$.

Kesimpulan: Ekstrak akar Acalypha indica Linn mampu meningkatkan viabilitas sel hipokampus dan kadar $B D N F$ endogen pada keadaan hipoksia. (Med J Indones. 2012;21:141-6)

\begin{abstract}
Background: This study was done to determine the effect of root extract of Acalypha indica Linn (akar kucing) in protecting neuron viability of the rat hippocampus on tissue culture in hypoxic condition.

Methods: This is an experimental study of in vitro primary cell culture of hippocampus of Sprague Dowley adult rat. The cultures were group into control (C) and exposure to root extract of Acalypha indica Linn with dose of $10 \mathrm{mg} / \mathrm{mL}, 15 \mathrm{mg} /$ $\mathrm{mL}$, and $20 \mathrm{mg} / \mathrm{mL}$ for 72 hours. The cultures were then exposed to hypoxic gas ( $5 \%$ oxygen, $5 \%$ carbondioxide, nitrogen balance) for 24 hours. After that, relative cell viability was measured by 3-[4,5-dimethylthiazol-2-yl]-2,5-diphenyltetrazolium bromide (MTT), cell proliferation by 5-bromo2'-deoxy-uridine (BrdU), and Brain-derived Neurotrophic Factor (BDNF) levels by BDNF ELISA kit.

Results: The result showed MTT viability (C: 99.7\%, A indica L 10: 326.3\%, A indica L 15: 411.7\%, A indica L 20: 445.9\%), BrdU absorbance (C: 0.07, A indica L 10: 0.10, A indica L 15: 0.12, A indica $\mathrm{L} 20: 0.13$ ) of the exposured hippocampal cell were significantly higher than the control group $(\mathrm{p}<0.01)$ accompany by increased level of BDNF $(\mathrm{C}: 11.3 \mathrm{pg} / \mathrm{mL}, A$ indica L 10: $12.5 \mathrm{pg} / \mathrm{mL}$, A indica L 15: $23.1 \mathrm{pg} / \mathrm{mL}$, A indica $\mathrm{L} 20: 18.1 \mathrm{pg} / \mathrm{mL}$ ).
\end{abstract}

Conclusion: The root extract of Acalypha indica Linn is able to improve rat hippocampal cell viability and endogenous BDNF levels in hypoxic condition. (Med J Indones. 2012;21:141-6)

Keywords: BDNF, hippocampal cell viability, hypoxia, root of Acalypha indica Linn

Stroke is the third cause of death in the world apart from cardiovascular disease and cancer. Prognosis of stroke are even worse than most cancer, in which half of all stroke patients die, and $15-30 \%$ of stroke survivors became disabled due to neurological deficits. ${ }^{1}$ Stroke arise from sudden interruption of blood supply to the brain, causing cerebral hypoxia which triggers a series of pathological cascade caused by glutamate excitotoxicity and excess production of free radicals. These could lead to the death of cells in brain within a few minutes..$^{2-4}$

The ability of brain cell to survive is affected by the role of growth factors, such as Brain-derived Neurotrophic
Factor (BDNF) that plays a role in survival, growth, and development of neuron. ${ }^{5}$ BDNF acts by limiting neuronal cell death through its ability to modulate survival signaling pathways, that function as a manifestation of endogenous body's defense mechanism. ${ }^{6}$ During hypoxia, protein synthesis is inhibited, therefore BDNF synthesis is also being supressed. However, endogenous BDNF levels will begin to increase after 24 hours to several days posthypoxia cerebri. ${ }^{7}$ Therefore, BDNF level can be used to measure neuronal cell growth and development.

Acalypha indica Linn (akar kucing) is a wild plant that can be found in every region in Indonesia. Kaempferol 
(flavonoids), contained in the Acalypha indica Linn root, has an antioxidant activity to protect neuronal cell from hypoxia-induced cell damage. ${ }^{8-10}$ Role of the $\operatorname{root}$ of $A$. indica Linn in muscular activity has been performed ex vivo study on frogs by Purwaningsih et $\mathrm{al}^{11}$ found that root of A. indica Linn improved contraction of $m$. gastrocnemius after being paralyzed with pancuronium bromide. However, muscular contraction activity does not directly indicate brain cell growth and development. Therefore, this research is conducted to determine the effect of Acalypha indica Linn root extract on viability of brain cell neuron and endogenous BDNF levels in hypoxic condition in vitro.

\section{METHODS}

\section{Study design and sample}

This was an in vitro experimental study on primary cell culture, which was taken from the hippocampus of adult Sprague Dowley rats aged 9-10 weeks, weighing 200-250 g. It was conducted at the Laboratory of Oral Biology, Faculty of Dentistry, Universitas Indonesia from January - March 2010. The animal were sacrificed by cervical dislocation. Ethical clearance was obtained from the committee of the medical research ethics of the Faculty of Medicine, Universitas Indonesia. The management of animals used was in accordance to the Helsinki convention.

\section{Nerve cell culture}

The total number of nerve cell culture samples was 24 samples (6 samples for every treatment group), based on Federer formula. Nerve cell culture were seeded at density of $20 \times 10^{6}$ cells into $0.1 \%$ PolyL-Lysin (Nacalai tesque) 1-2 hours coated 100 $\mathrm{mm}$ diameter sterile plates. Cell were maintained in Dulbecco's modified Eagle's medium (DMEM, Gibco) supplemented with 10\% FBS (Sigma), 1\% Penn-Strep dan 1\% Fungizone (Sigma). Cultures were maintained at $37^{\circ} \mathrm{C}$ in a humidified $5 \% \mathrm{CO} 2$ atmosphere. During the incubation period, medium was replaced every 3 days and cells were observed with phase-contrast microscope, Nikon Eclipse 80i, magnification 10x. Experiments were conducted at 10 days in vitro.

\section{Exposed to Acalypha indica Linn root extract and hypoxia}

To examine the effect of $A$. indica Linn on cell viability and cell proliferation, cell were subculture into $0.1 \%$ Poly-L-Lysin-coated 24-well plates at a density of
$5 \times 10^{5}$ cell/ well to measured cell viability and into $0.1 \%$ Poly-L-Lysin-coated 96-well plates at a density of $1 \times 10^{5}$ cells/ well to measured cell proliferation. Subculture cell were divided into control and exposure group. Exposure group were exposed to A. indica Linn root water extract (Department of Pharmacy, Faculty of Medicine Universitas Indonesia) with a dose of $10 \mathrm{mg} / \mathrm{mL}, 15 \mathrm{mg} / \mathrm{mL}$, and $20 \mathrm{mg} / \mathrm{mL}$ for 72 hours. The subculture cell then exposed to hypoxic gas $(5 \%$ $\mathrm{O} 2 / 5 \% \mathrm{CO} 2 / \mathrm{N} 2$ balance) for 24 hours. ${ }^{12}$ After exposure to hypoxia, cell viability was measured by MTT assay, the level of cell proliferation was analyzed by BrdU labeling and the levels of BDNF in the culture medium was analyzed using a BDNF ELISA kit.

\section{Cell viability}

Cell viability was assayed by 3-[4,5-dimethylthiazol2-yl]-2,5-diphenyltetrazolium bromide (MTT, Sigma). Culture were incubated with $5 \mathrm{mg} / \mathrm{mL}$ MTT at $37^{\circ} \mathrm{C}$ for 3 hours, then the optical density of the assay was measured in ELISA reader with a wavelength of $490 \mathrm{~nm}$.

\section{Cell proliferation}

Cell proliferation was assayed by 5-bromo2'-deoxyuridine (BrdU, Roche Applied Science Cat. 11444611 001). BrdU incorporation was performed according to standard procedures listed in the manual kit. Measurement of absorbance by ELISA reader at 405 $\mathrm{nm}$ with reference wavelength of $490 \mathrm{~nm}$.

\section{BDNF levels}

Samples for measurement of BDNF levels were taken from 24 well plate neuronal culture medium immediately after hypoxic treatment. Culture medium then were centrifuged, the supernatant was taken and stored in $-20^{\circ} \mathrm{C}$ until the BDNF level measurement will be conducted. BDNF level was examined by BDNF kit (BDNF, sandwich ELISA kit CYT 306, Chemicon International) and was performed according to standard procedures listed in the manual kit and measurement on ELISA reader with a wavelength of $450 \mathrm{~nm}$.

\section{Data analysis}

Data processing was done using SPSS version 16 software. The statistical significance of difference between means of cell viability, cell proliferation, and BDNF level were tested by ANOVA one way after the test for normality and homogenity. If there was a data with abnormal distribution and variance, data transformation will be done. And, if the distribution remains abnormal after the data transformation, non- 
parametric Kruskal Wallis test was done. $\mathrm{P}<0.05$ was considered significant.

\section{RESULTS}

MTT examination to measure the relative cell viability was performed in triplo. Average mean relative cell viability in the control group was $99.7 \pm 6.98 \%$; exposure group $A$ indica Linn root extract $10 \mathrm{mg} / \mathrm{mL}$ was 326.30 $\pm 43.73 \%$; exposure group $A$ indica Linn root extract 15 $\mathrm{mg} / \mathrm{mL}$ was $411.65 \pm 114.25 \%$, and exposure group $A$ indica Linn root extract $20 \mathrm{mg} / \mathrm{mL}$ was $445.91 \pm 67.37 \%$ (Figure 1). The relative cell viability of each exposure extract group was significantly higher compared with the control group $(p<0.01)$. Viability of cell exposure group $A$ indica Linn root extract $15 \mathrm{mg} / \mathrm{mL}$ was higher than group $A$ indica Linn root extract $10 \mathrm{mg} / \mathrm{mL}$, and the viability of hippocampal cell in exposure group $A$ indica Linn root extract $20 \mathrm{mg} / \mathrm{mL}$ was higher than group $A$ indica Linn root extract $15 \mathrm{mg} / \mathrm{mL}$. While the cell viability of exposure group $A$ indica Linn root extract $20 \mathrm{mg} / \mathrm{mL}$ was significantly higher than group $A$ indica Linn root extract $10 \mathrm{mg} / \mathrm{mL}(\mathrm{p}<0.05$; Figure 1$)$.

BrdU labeling to measure the level of cell proliferation, was performed in duplo. Absorbance obtained in the control group was $0.072 \pm 0.0095$, exposure group $A$ indica
Linn root extract $10 \mathrm{mg} / \mathrm{mL}$ was $0.104 \pm 0.0146$, exposure group $A$ indica Linn root extract $15 \mathrm{mg} / \mathrm{mL}$ in $0.117 \pm$ 0.0187 , and exposure group $A$ indica Linn root extract 20 $\mathrm{mg} / \mathrm{mL}$ in $0.134 \pm 0.0135$ (Figure 2). Cell proliferation rate of each exposure group was significantly higher than the control group, with the highest rate in the exposure group $A$ indica Linn root extract $20 \mathrm{mg} / \mathrm{mL}$.

On measurement of BDNF levels in the culture medium, it has been found that BDNF levels in the control group was $11.31 \mathrm{pg} / \mathrm{mL}$, exposure group $A$ indica Linn root extract $10 \mathrm{mg} / \mathrm{mL}$ was $12.49 \mathrm{pg} / \mathrm{mL}$, exposure group $A$ indica Linn root extract $15 \mathrm{mg} / \mathrm{mL}$ was $23,14 \mathrm{pg} /$ $\mathrm{mL}$, and exposure group $A$ indica Linn root extract 20 $\mathrm{mg} / \mathrm{mL}$ was $18.11 \mathrm{pg} / \mathrm{mL}$ (Figure 3 ). BDNF level was highest in the exposure group root extract $15 \mathrm{mg} / \mathrm{mL}$ and lower in the exposure group $A$ indica Linn root extract $20 \mathrm{mg} / \mathrm{mL}$, but still higher than control group and exposure group root extract $10 \mathrm{mg} / \mathrm{mL}$.

\section{DISCUSSION}

This study showed that the Acalypha indica Linn root extract was able to increase the relative cell viability of neuron in hypoxic condition. These results were apparent from MTT examination, which showed that the relative cell viability was increased in neuron that

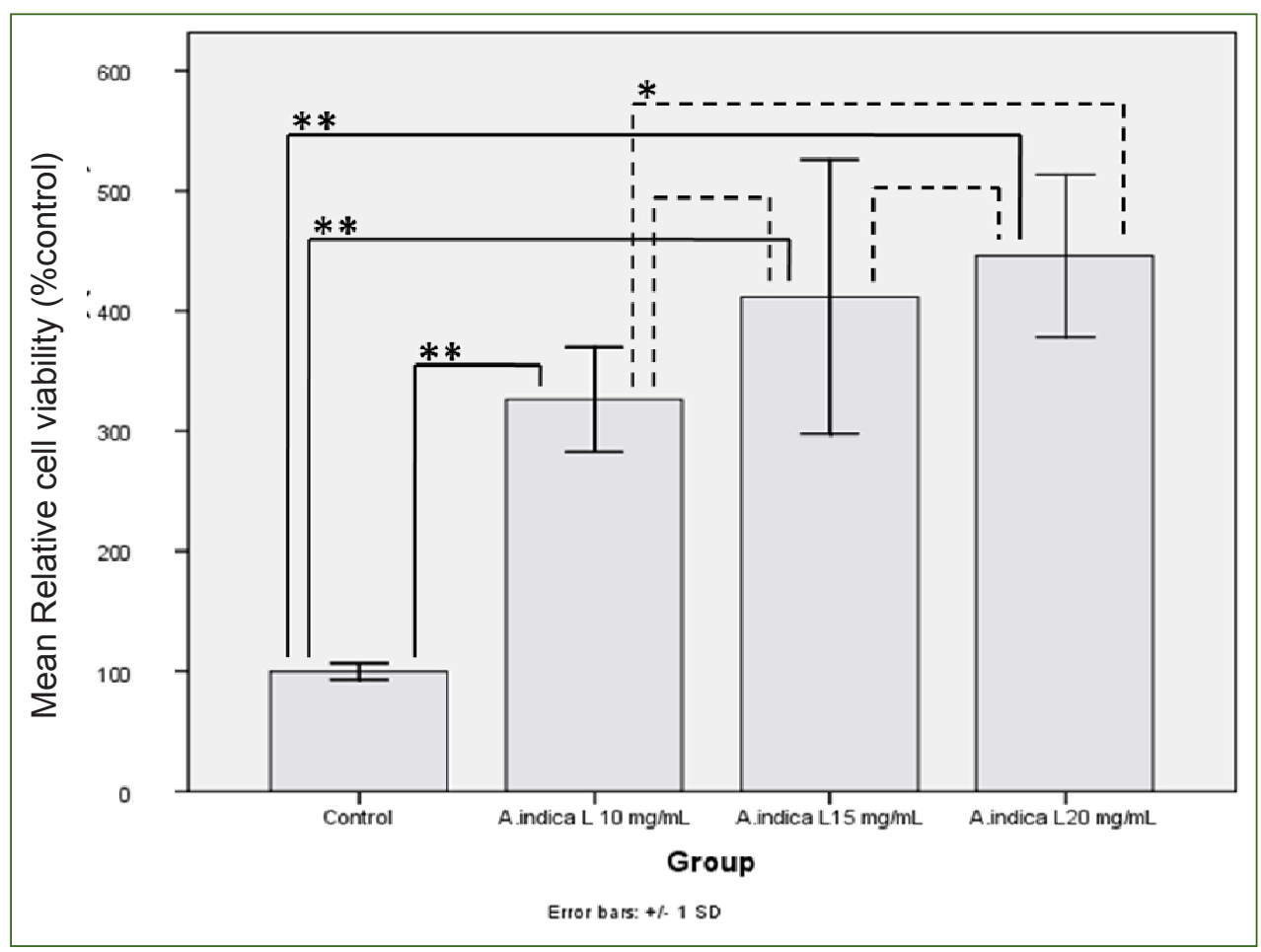

Figure 1. The mean relative percentage of neuronal viability

Mean relative viability whole cell groups exposed to A indica Linn root extracts $10 \mathrm{mg} / \mathrm{mL}$, $15 \mathrm{mg} / \mathrm{mL}$, and $20 \mathrm{mg} / \mathrm{mL}$ were increased compared to control $(* * \mathrm{p}<0.01, * \mathrm{p}<0.05$ ) Note: — compared to control, - - - - compared to other group 


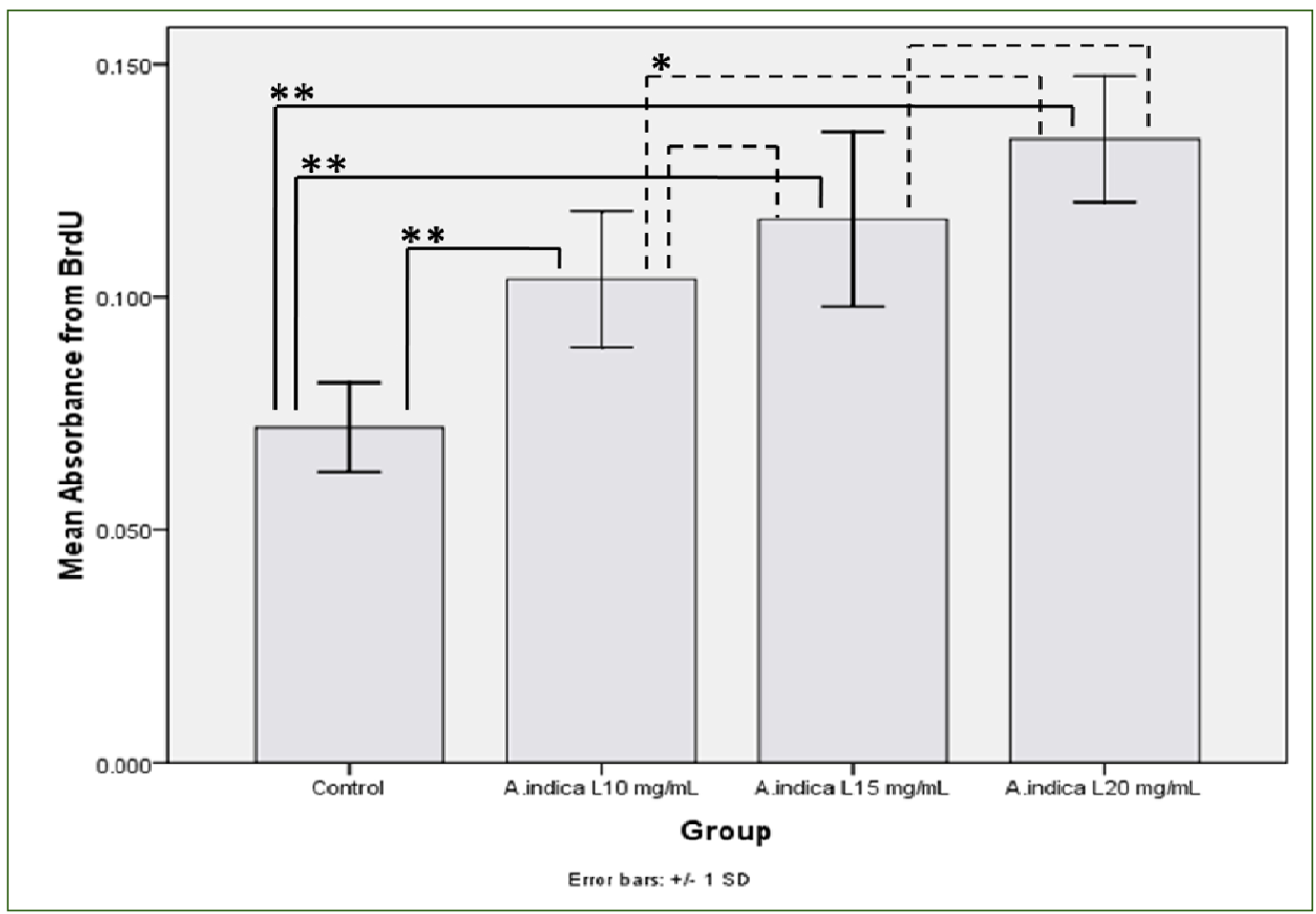

Figure 2. Mean BrdU absorbance value

Mean BrdU absorbance groups exposed to A indica Linn root extracts $10 \mathrm{mg} / \mathrm{mL}, 15 \mathrm{mg} / \mathrm{mL}$, and 20 $\mathrm{mg} / \mathrm{mL}$ were increased compared to control $(* * \mathrm{p}<0.01, * \mathrm{p}<0.05)$

Note: — compared to control, - - - - compared to other group

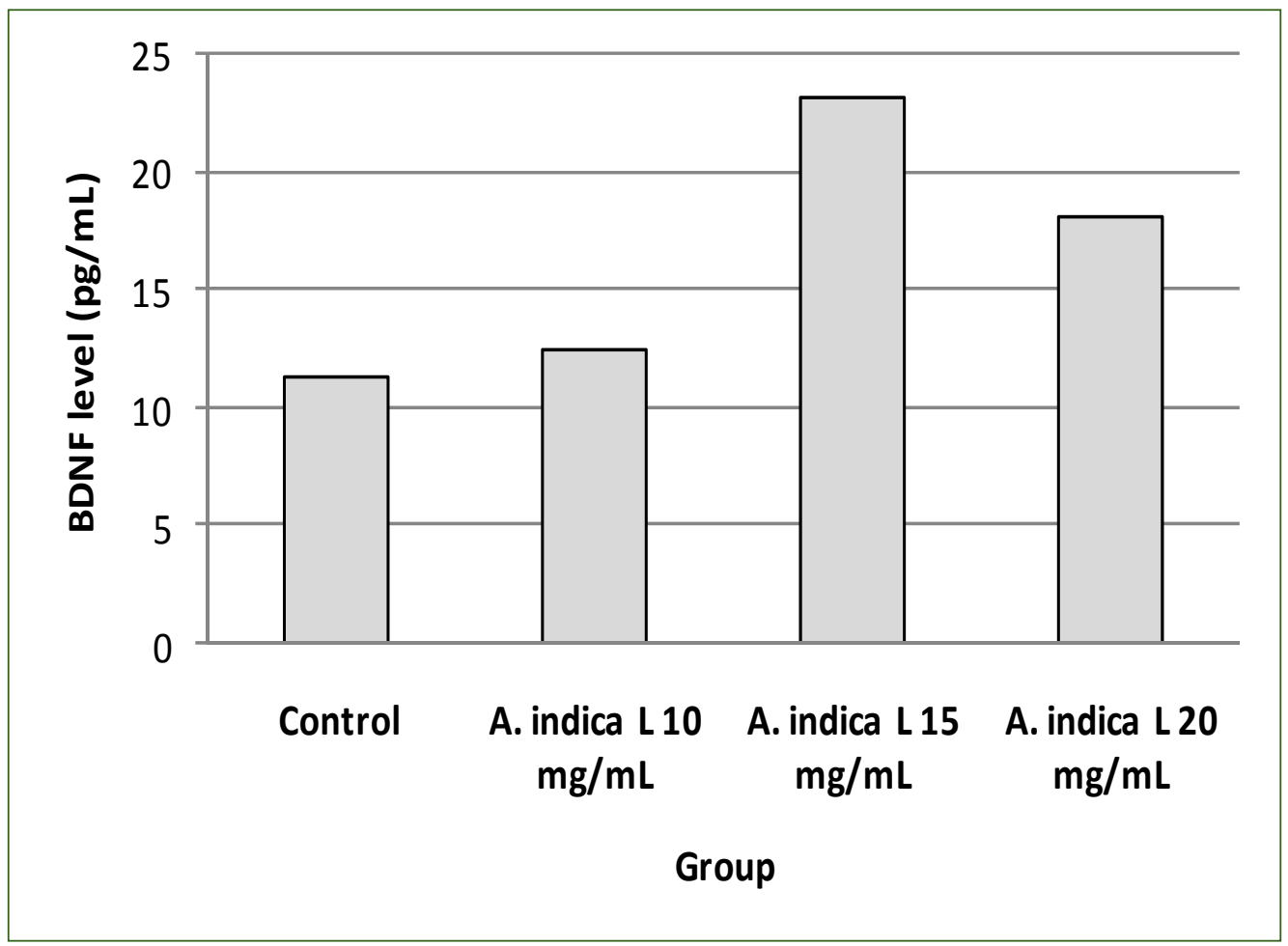

Figure 3. BDNF neuron levels

$B D N F$ neuron level groups exposed to A indica Linn root extracts $10 \mathrm{mg} / \mathrm{mL}, 15 \mathrm{mg} / \mathrm{mL}$, and

$20 \mathrm{mg} / \mathrm{mL}$ were increased compared to control.

* Sample taken from pooled of 6 samples / group 
have been exposed to Acalypha indica Linn root extract compared to the control group, even reach to 4-fold increase in the group that has been exposed to $15 \mathrm{mg} / \mathrm{mL}$ and $20 \mathrm{mg} / \mathrm{mL}$ of Acalypha indica Linn root extract. An increase in relative cell viability was consistent with the increased doses and was statistically significant $(\mathrm{p}<0.01)$ compared to the control group.

Living cells are actively proliferating so the viability of neuron can also be seen by its activeness in proliferation. Therefore, another examination was conducted to evaluate the effect of Acalypha indica Linn on neuronal viability based on the level of cell proliferation. Cell proliferation was examined by the BrdU labeling, which indicated that the Acalypha indica Linn root extract also influenced the level of proliferation, as shown by the increase in absorbance/ proliferation level with a pattern similar to that of levels of neuronal viability. The proliferation rate of the group that has been exposed to $10 \mathrm{mg} / \mathrm{mL}$ of Acalypha indica Linn root extract was increased by 1.5 -fold compared with the control group, whereas those which have been exposed to $15 \mathrm{mg} / \mathrm{mL}$ and $20 \mathrm{mg} / \mathrm{mL}$ resulted in a up to 2-fold increase of proliferation levels compared to the control group. All of these improvements were in accordance with the increased doses and statistically significant $(\mathrm{p}<0.01)$ compared to the control group. Thereby the results of this study is in line with research conducted by Purwaningsih et $\mathrm{al}^{11}$ in which the water extract of Acalypha indica Linn roots provide optimal neuroprotective and neurotherapeutic effect at doses of $15 \mathrm{mg} / \mathrm{mL}$ and $20 \mathrm{mg} / \mathrm{mL}$ in ex vivo neuromuscular paralysis on frog.

The ability of the Acalypha indica Linn root extract in improving the viability of neuron was estimated to be related to the active substance contained in the extract of the roots, which is flavonoids (kaempferol) and phenolic components (tannins). Flavonoids are one of the powerful antioxidant. It is reportedly has a potential neuroprotective effects in preventing neuronal damage caused by ischemic stroke, by interrupting the cascade of cell death by glutamate excitotoxicity, including preventing the formation of ROS and inhibiting the entry of calcium into cell. ${ }^{10,13}$ Research that was conducted by Balakrishnan et $\mathrm{al}^{9}$ proved that the active substances mentioned above, which were contained in the Acalypha indica Linn root extract, were able to counteract the effects of NO free radicals by suppressing radical formation. These capabilities were related to the antioxidant activity of active substances in the Acalypha indica Linn roots and reportedly equivalent to the antioxidant activity of ascorbic acid (vitamin C). ${ }^{8}$ Some studies also reported the ability of kaempferol (a flavonoid contained in the Acalypha indica Linn roots) against neuronal excitotoxicity and mitochondrial dysfunction, which significantly reduce mortality and improve neuron survival. ${ }^{13-15}$ This ability is related to the activity of antioxidants contained in kaempferol, directly, inhibits the formation of free radicals which was generated by mitochondria. ${ }^{14}$ Thus, the existence of active substances in Acalypha indica Linn roots has been suspected to play a role in preventing brain's cell death during hypoxia, as seen from the increased viability of the cell.

Improved viability of brain's cell is in line with the increased doses, and there is a possibility that a higher dose of the root extract of Acalypha indica Linn, can further improve the cell viability. So, a study with a higher dose of Acalypha indica Linn extract needs to be done to get the optimal dose for increasing the viability of brain's cell in hypoxic conditions. Several other herbs have also been investigated and had been reported to have an efficacy in protecting neurons against damage caused by hypoxia. Among them were Brazilian green propolis ${ }^{16}$ and Allium cepa ${ }^{17}$ (onion). Flavonoid substances that contained in those herbs, as that of Acalypha indica Linn, have an antioxidant properties which able to counteract freeradicals that causing neuronal impairment, thereby neuronal death could be prevented. Although there were no studies comparing them with the effects of Acalypha indica Linn roots, it is still possible that Acalypha indica Linn has the same or-even-better potency.

In addition, the ability of brain's cell to survive is also affected by neurotrophic factors, such as BDNF, by maintaining the life and limiting the death of brain's cell. The results showed an increase in BDNF levels in the exposure group of 10,15 , and $20 \mathrm{mg} / \mathrm{mL}$ root extract, compared with the control group. Thus, BDNF also influential in maintaining the survival of brain cell during hypoxic condition, in accordance with the increased proliferation of cell. At the dose of $15 \mathrm{mg} /$ $\mathrm{mL}$, an optimal levels of BDNF was obtained. This result is in line with the increased proliferation that began to optimize at the dose of $15 \mathrm{mg} / \mathrm{mL}$. In this study, it appears that the survival ability of neuron is based on the increasing viability and proliferation level. So, in addition to the role of BDNF, the root extract of Acalypha indica Linn also affects the survival of cell, by its ability to counteract free radicals, resulting in the prevention of cells death. Acalypha indica Linn root extract, with its antioxidant capability, contribute directly to the production of endogenous BDNF by preventing damage against proteins and inhibiting of protein synthesis. Grant et $\mathrm{al}^{18}$ has reported that the antioxidant contained in the ascorbic acid could induced 
the expression of BDNF genes during the oxidative damage. Guo et $\mathrm{al}^{19}$ also reported that administration of antioxidants was able to overcame free radicals effects, resulting in increased synthesis of endogeneous BDNF. Roots of Acalypha indica Linn contains antioxidant substances that reportedly equivalent to ascorbic acid in dealing with free radicals, ${ }^{8}$ thus able to induce BDNF gene expression during hypoxia.

This study has a limitation. Because we can not obtained the specific marker to confirmed whether the cell were neuron, the hippocampal cell that were used in this study were identified morphologically. However, there still remain a possibility that some of the cells are neuron, due to the increasing level of BDNF. Hence continued research on the isolation of nerve cell by using specific neuronal markers such as, neuron-spesific enolase type 2 , to increase the level of confidence in research results is needed.

In conclusion, the root extract of Acalypha indica Linn is able to improve rat hippocampal cells viability and endogenous BDNF levels in hypoxic condition.

\section{Acknowledgment}

The research was funded by Hibah Riset Unggulan Universitas Indonesia (RUUI) contract no. 747M/ DRPM-UI/A/N1.4/2009 and Atma Jaya scholarship. We would like to thank the chief of Oral Biology Laboratory, drg. Endang Winiati Bachtiar, M. Biomed, $\mathrm{PhD}$, and all of the staff for giving an useful advice, support, and assistance during the research.

\section{REFERENCES}

1. $\mathrm{Wu} \mathrm{D}$. Neuroprotection in experimental stroke with targeted neurotrophins. NeuroRx. 2005;2(1):120-8.

2. Fulda S, Gorman AM, Hori O, Samali A. Cellular stress responses: cell survival and cell death. Int $\mathrm{J}$ Cell Biol. 2010;2010:1-23.

3. Yakovlev AG, Faden AI. Mechanisms of neural cell death: implications for development of neuroprotective treatment strategies. NeuroRx. 2004;1:5-16.

4. Culmsee C, Krieglstein J. Ischaemic brain damage after stroke: new insights into efficient therapeutic strategies. EMBO Rep. 2007;8:129-33.

5. Binder DK, Scharfman HE. Brain-derived neurotrophic factor. Growth Factors. 2004;22:123-31.
6. Sugawara T, Fujimura M, Noshita N, Kim GW, Saito A, Hayashi $T$, et al. Neuronal death/survival signaling pathways in cerebral ischemia. NeuroRx. 2004;1:17-25.

7. Kitagawa K. CREB and c-AMP response elementmediated gene expression in the ischemic brain. FEBS J. 2007;274:3210-7.

8. Indian Medicinal Plants Growers' Consortium. Acalypha indica L [Internet]. 2007 [cited 2009 Jan 12]. Available from: impgc.com.

9. Balakrishnan N, Panda AB, Raj NR, Shrivastava A, Prathani R. The evaluation of nitric oxide scavenging activity of Acalypha indica Linn root. Asian J Res Chem. 2009;2:148-50.

10. Vauzour D, Vafeiadou K, Mateos AR, Rendeiro C, Spencer JPE. The neuroprotective potential of flavonoids: a multiplicity of effects. Genes Nutr. 2008;3:115-26.

11. Purwaningsih EH, Ibrahim N, Zain H, Tedjo A. Neuroprotection and neuro-therapy effects of Acalypha indica Linn water extract ex vivo on musculus gastrocnemius frog. Makara Seri Kesehatan. 2008;12:71-6.

12. Gozal E, Sachleben LR Jr, Rane MJ, Vega C, Gozal D. Mild sustained and intermittent hypoxia induce apoptosis in PC-12 cells via different mechanisms [Internet]. Am J Physiol Cell Physiol. 2005 [cited 2010 Jan 20];288:535-42. Available from: www.ajpcell.org.

13. Dajas F, Rivera-Megret F, Blasina F, Arredondo F, AbinCarriouiry JA, Costa G, et al. Neuroprotection by flavonoids. Braz J Med Biol Res. 2003;36(12):1613-20.

14. Samhan-Arias AK, Martin-Romero FJ, Gutierrez-Merino C. Kaempferol blocks oxidative stress in cerebellar granule cells and reveals a key role for reactive oxygen species production at the plasma membrane in the commitment to apoptosis. Free Radic Biol Med. 2004;37:48-61.

15. Silva B, Oliveira PJ, Dias A, Malva JO. Quercetin, kaempferol and biapigenin from Hypericum perforatum are neuroprotective against excitotoxic insults. Neurotox Res. 2008;13(3-4):265-79.

16. Shimazawa M, Chikamatsu S, Morimoto N, Mishima S, Nagai $\mathrm{H}$, Hara H. Neuroprotection by Brazilian Green Propolis against in vitro and in vivo ischemic neuronal damage. Evid Based Complement Alternat Med. 2005;2(2):201-7.

17. Shri R, Bora KS. Neuroprotective effect of methanolic extracts of Allium cepa on ischemia and reperfusioninduced cerebral injury. Fitoterapia. 2008;79:86-96.

18. Grant MM, Barber VS, Griffiths HR. The presence of ascorbate induces expression of brain derived neurotrophic factor in SH-SY5Y neuroblastoma cells after peroxide insult, which is associated with increased survival. Proteomics. 2005;5:534-40.

19. Guo S, Kim WJ, Lok J, Lee SR, Besancon E, Luo BH, et al. Neuroprotection via matrix-trophic coupling between cerebral endothelial cells and neurons. Proc Natl Acad Sci U S A. 2008;105(21):7582-7. 